日作紀（Jpn. J. Crop Sci.） $74 （ 4 ） ： 456-458$ （2005）

\title{
連載ミニレビュー
}

\section{作物の形態研究法：マクロからミクロまで 免疫電子顕微鏡法の実際}

\author{
上野修 \\ （農業生物資源研究所）
}

免疫電子顕微鏡法は，免疫組織細胞化学の一手法である。この方法では，抗原抗体反応を利用して，組織切片上で 酵素等の蛋白質（抗原）の局在部位を標識し，電子顕微鏡下で観察する。これにより，対象とする蛋白質が組織細胞 のどの部位にどの位蓄積しているのかを的確に知ることができ，組織細胞の構造と生理生化学的機能を結びつけて理 解する上できわめて有効な手法である。ここでは, 著者が葉における光合成代謝酵素の局在解析で日頃行っている, 超薄切片を用いたプロテイン A・金コロイド免疫電子顕微鏡法の実験手法を概説する.

\section{1. 免疫電子顕微鏡法とは}

生体組織には酵素を始めとする各種の蛋白質が含まれて いる。これらの蛋白質の存在や蓄積量を解析するには，一 般には生組織から蛋白質を抽出した後電気泳動にかけ，目 的の蛋白質に対する抗体を用いて検出同定する（ウエス夕 ンブロット法)。しかし，この方法では組織細胞のどこに 目的の蛋白質が蓄積しているのかを知ることはできない. これを知るためには，組織をあらかじめ細胞やオルガネラ に分画し蛋白質の局在を解析することになるが，このとき コンタミネーションや回収率の問題が生ずる。中には分画 すること自体，不可能な組織もある。これに対し免疫電子 顕微鏡法では，生体組織を化学的に固定した後組織切片を 作製し，抗原抗体反応を組織切片上で行わせる。その後金 コロイド粒子で抗原の局在部位を標識することにより可視 化し，蛋白質の存在を透過型電子顕微鏡下で間接的に観察 する（Bendayan 2000）。このため，細胞分画法で直面する 多くの問題を回避することができる.

第 1 図にプロテイン $\mathrm{A}$ ・金コロイド免疫電子顕微鏡法の 原理を示す。グリッド上に載せられた超薄切片の表面には 各種の蛋白質が露出している（第 1 図 A)。まず，切片に 目的の蛋白質（抗原）を特異的に認識する抗体を処理して, 切片表面の抗原との間で抗原抗体反応を起こさせる（第 1 図 B)。このままでは，抗原の存在部位を見ることはでき ないので，切片表面の抗原と結合している抗体をプロテイ ン A・金コロイド複合体で標識する (第 1 図 C)。これは, プロテイン A（黄色ブドウ球菌の膜蛋白質）が抗体 IgG の Fc フラグメントと特異的に結合する性質による.この結果, 切片上における抗原の局在位置が金コロイド粒子の標識と して電子顕微鏡下で観察される（第 2 図）。

\section{2. 方法の概要}

\section{(1) 試料の固定}

免疫電子顕微鏡用の植物試料の固定法は，基本的には通 常の透過型電子顕微鏡試料の固定操作と同じであるが，い くつかの相違点がある。オスミウム酸は蛋白質の抗原性を 著しく低下させるので用いない，また，蛋白質の変成をで きるだけ抑えるため低温下で行う。グルタルアルデヒドは 抗原性を低下させやすいので，パラホルムアルデヒドがよ く用いられる。著者は，3\%パラホルムアルデヒド- $0.2 \%$
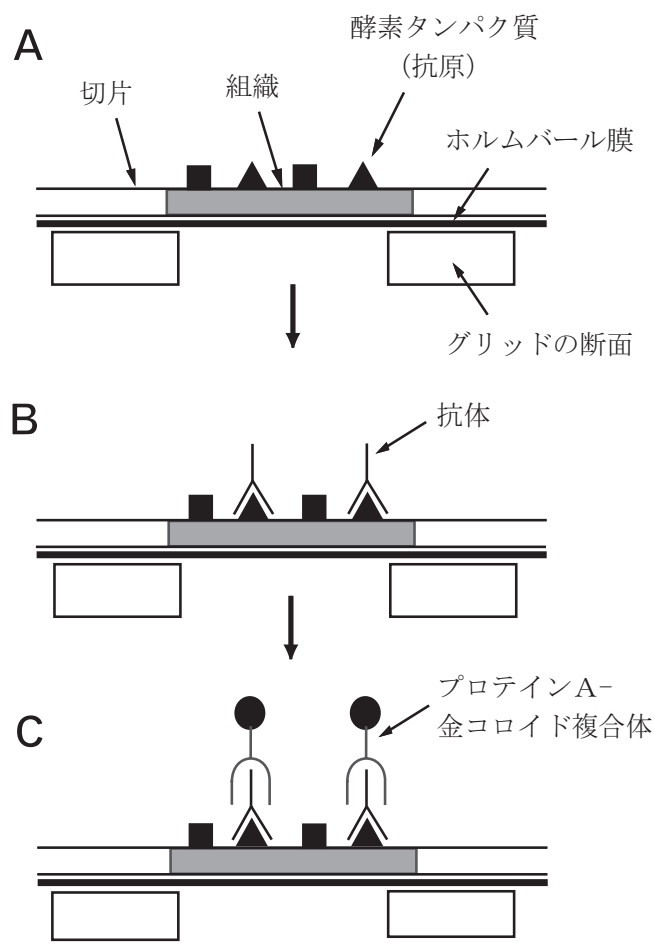

第 1 図 プロテインA・金コロイド免疫電子顕微鏡法の原理 


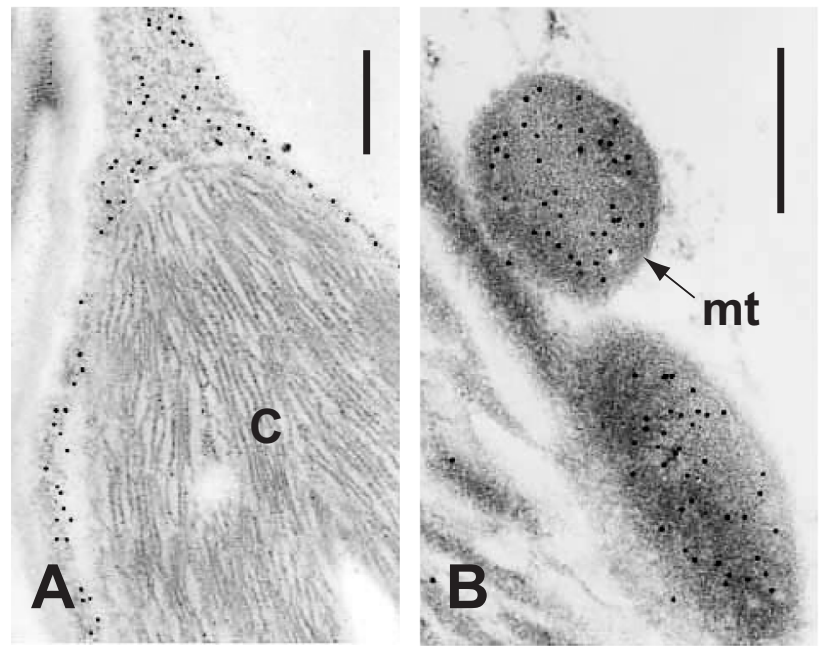

第 2 図 プロテインA・金コロイド免疫電子顕微鏡法による光合成およ び光呼吸酵素の局在解析. $\mathrm{A}$ :アマランサス $\left(\mathrm{C}_{4}\right.$ 型 $)$ 葉肉細胞の 細胞質におけるPEP-カルボキシラーゼの標識. B:キャッサバ ( $\mathrm{C}_{3}$ 型) 葉肉細胞のミトコンドリア $(\mathrm{mt})$ におけるグリシンデカルボキ シラーゼP蛋白質の標識. C:葉緑体. スケール: $0.5 \mu \mathrm{m}$.

グルタルアルデヒドーリン酸緩衝液（pH 6.8）により固定 するか，光合成代謝酵素のように葉内に多量に蓄積してい る蛋白質では, $3 \%$ グルタルアルデヒドーリン酸緩衝液 $(\mathrm{pH}$ 6.8）により固定している. 微量な蛋白質の検出では前者 の固定液が優れているが，微細構造保持の点では後者の方 がやや勝る.

植物試料に少量の固定液をたらし，カミソリの刃を用い て $1 \mathrm{~mm}$ 以下に細切した後，管瓶の中で固定する。著者は， 葉の場合厚さ $0.3 \sim 0.4 \mathrm{~mm}$, 幅 $1 \mathrm{~mm}$ 位の切片にして固 定している，管瓶は氷冷する，以後，液の交換は試料を管 瓶内に残したまま，パスッールピペット等で液を吸い取る ことにより行う。なお，植物組織は細胞間隙が発達してい るので，固定の最初の段階でアスピレーターにより脱気す る必要がある。固定時間は植物材料により異なるが，イネ 科植物の葉身で 3 時間位である。その後，氷冷したリン酸 緩衝液で 30 分おきに 3 回洗浄する.

\section{（2）脱水および包埋}

エタノール $(30 \%, 50 \%, 80 \%, 95 \%, 100 \%, 100 \%$, 各 30 分）により脱水する。そ後, Lowicryl K4M 樹脂と エタノールの混合液 $(1: 2,1: 1,3: 1$, 各 2 時間) の中で 徐々に組織内のエ夕ノールを樹脂と置換し，100\%の Lowicryl K4M 樹脂の中に一晚おく。さらに新しい Lowicryl $\mathrm{K} 4 \mathrm{M}$ 樹脂と交換して 1 日おく. 50\%エタノール以降の操 作は冷凍室 $\left(-20^{\circ} \mathrm{C}\right)$ で行う。 Lowicryl K4M 樹脂は粘度が 低いので回転浸透器にかける必要はないが，ときどき液を 擋汼する。

組織片はゼラチンカプセルかビームカプセルの中で包埋 し，紫外線を1 日照射することにより重合させる。専用の 紫外線重合装置が市販されている。重合中に熱が発生する
ので，抗原性の低下を防ぐために，装置は冷凍室の中に入 れる (Lowicryl K4M 樹脂は $-35^{\circ} \mathrm{C}$ までの低温重合が可能). 完成した樹脂ブロックはシリカゲルを入れた密栓容器の中 に入れ，冷蔵庫内に保管する。 Rubisco や $\mathrm{C}_{4}$ 植物の PEPカルボキシラーゼのように多量に蓄積している酵素蛋白質 であれば， 1 年間位保管したブロックでも十分検出できる. なお，免疫電子顕微鏡用の樹脂としては，LR White や LR Goldもしばしば用いられる（安田 1986）。

\section{(3) 薄切}

超薄切片の作製法は，通常の透過型電子顕微鏡試料の方 法と違いはない．ホルムバール支持膜を張ったグリッドの 上にシルバーゴールド位の切片を載せる．Lowicryl K4M 樹 脂は親水性であるため, ブロックの切り出し面に水滴が付 かないよう注意する，樹脂が水分を吸うと，超薄切片の作 製は難しくなる。また，ブロックを一度トリミングし時間 がたつと, 樹脂が変成し再度の薄切が難しくなるので, 一 度に切片を作成する。

\section{(4) 抗原抗体反応と標識}

1） $0.5 \%$ 牛血清アルブミン（BSA）を含むPBST 溶液， 30 分

2）上記溶液で希釈した抗体（数時間から一晚）

3）PBST による洗浄（各 10 分，3 回）

4） $0.5 \% \mathrm{BSA}$ を含む PBST で希釈したプロテイン A・金 コロイド複合体溶液（30 分）

5）PBSTによる洗浄（各 5 分，4回）

6）蒸留水による洗浄 (各 5 分， 3 回)

7）乾燥

PBST は $0.15 \mathrm{M} \mathrm{NaCl} と 0.1 \%$ Tween 20 を含む $0.01 \mathrm{M}$ リン酸緩衝液（pH 7.2）である。以上の操作は、シャーレ 内の水を浸した濾紙の上にパラフィルムをしき, 滴下した 水滴 $(20 \sim 30 \mu \mathrm{L})$ にグリッドを浮かべて（切片面を下）, 順次移動させて行く。最初の BSA 処理は非特異的反応を 抑えるために行う (ブロッキング)。抗体の至適濃度と至 適反応時間は，自身で見出す，処理時間が長い場合は冷蔵 庫の中におく，著者は，Rubisco の場合 1000 倍希釈で 3 時 間 (室温), PEP-カルボキシラーゼでは 500 倍希釈で一晚 $\left(4^{\circ} \mathrm{C}\right)$ 処理している。 また，使用する抗体が目的の蛋白質 を特異的に認識することを，事前にウエスタンブロット等 により確認しておくことが重要である，特異性の低い抗体 を用いて実験しても，何ら信頼できる結果を得ることはで きない．信頼できる反応性の高い抗体を用いることが，実 験成功のポイントとなる。プロテイン A・金コロイド複合 体は自作することもできるが (Bendayan 2000), 市販され ているもので十分良好な結果を得ることができる，希釈度 は 40 倍位であるが，これも自身で至適濃度を見出す。最 後に通常の方法に従い, 切片を䣷酸ウランとクエン酸鉛で 電子染色する，オスミウム酸固定を省いているので電子顕 
微鏡像のコントラストは低い.

コントロールとして，少なくとも2）の溶液から抗体を 除いた場合と抗体を非免疫血清に変えた場合について実験 を行い, 得られた標識が目的の蛋白質に対して特異的であ ることを確認する.

ブロックから厚さ $1 \mu \mathrm{m}$ 位の準超薄切片を作製しスライ ドグラスに張り付け，金コロイド標識を行った後，銀増感 することにより光学顕微鏡下で蛋白質の局在を観察するこ ともできる。詳細は，出村（1997）を参照されたい.

\section{3. 解析例}

免疫電子顕微鏡法は，植物では光合成や炭水化物代謝を 始め，様々な代謝に関わる酵素蛋白質の局在解析に用いら れているほか (Ueno 1992, Kawasaki ら 2002), 貯蔵蛋白質, 糖蛋白質, 膜輸送蛋白質, 植物ホルモン等の解析にも活用 されている (Herman 1988)。また，走査型電子顕微鏡によ る植物試料表面における蛋白質の検出にも用いられる (Miyake ら 2001).

金コロイド免疫電子顕微鏡法は，金粒子の標識密度（切 片像の単位断面積当たりの金粒子の数）を測定することに より，蓄積している蛋白質の相対的な量を評価できるとい う利点をもつ。これは, 標識密度の高低は切片上の抗原濃 度の高低を表していると考えることに基づく．アブラナ科 の $\mathrm{C}_{3}-\mathrm{C}_{4}$ 中間植物種と $\mathrm{C}_{3}$ 植物種との間で作出した人為交 雑植物では, 両親との中間的な光呼吸ガス交換特性を示す. 免疫電子顕微鏡法による光呼吸鍵酵素グリシンデカルボキ シラーゼ（GDC）の標識密度の解析から，この光呼吸活性 の違いは維管束鞘細胞におけるミトコンドリアの発達程度 と, 葉肉細胞と維管束鞘細胞のミトコンドリアにおける GDC の発現量の調節に基づくことが明らかになった (Ueno ら 2003). キャッサバ葉では背軸表皮に気孔をもつが（下 面気孔葉)，免疫電子顕微鏡法による解析から，GDC は海 綿状組織よりも柵状組織のミトコンドリアで強く発現して いることが明らかとなり，葉内部の組織の間で光呼吸活性 に違いがあることが示唆された（Ueno and Agarie 1997）.

免疫電子顕微鏡法で得られた結果が，生化学的手法によ り得られた結果と常に一致するのかは注意を要する。免疫 電子顕微鏡法では組織を化学的に固定し，脱水，包埋する ため, この過程で抗原性の低下がおこる可能性を排除でき ない. しかし, イネ科 $\mathrm{C}_{4}$ 植物の維管束鞘細胞ミトコンド リアにおけるGDCの蓄積量の種間差に関する研究では, 免疫電子顕微鏡法とウエスタンブロット法で得られた結果
とは互いによく一致することが報告されている（Yoshimura ら 2004). 組織内に広く微量に蓄積している蛋白質では, 免疫電子顕微鏡法では検出できなくとも, ウエスタンブ ロット法では検出されることがある。また逆に, 組織全体 としては微量であるが, 組織内のある特定部位に局在して いる蛋白質では，ウエスタンブロット法では検出できない が，免疫電子顕微鏡法では検出されることもある。常にそ れぞれの手法の長所と欠点を十分に念頭において, 実験を 進めることが必要であろう。

\section{引用文献}

Bendayan, M. 2000. A review of the potential and versatility of colloidal gold cytochemical labeling for molecular morphology. Biotechnic Histochem. 75 : 203-242.

出村拓 1997. イムノゴールド・シルバー染色法によるタンパク質の 局在解析法. 福田裕穂・西村幹夫・中村研三, 植物の細胞を観る実 験プロトコール.秀潤社, 東京. 95-99.

Herman, E.M. 1988. Immunocytochemical localization of macromolecules with the electron microscope. Ann. Rev. Plant Physiol. Plant Mol. Biol. 39 : $139-155$.

Kawasaki, M., T. Matsuda, Y. Nakamura, O. Ueno, M. Taniguchi, Y. Nitta and H. Miyake 2002. Structural and immunocytochemical characterization of the synthesis and accumulation of starch in sweet potato (Ipomoea batatas Lam.) tuberous root. Plant Prod. Sci. 5 : 152159.

Miyake, H., M. Nishimura and Y. Takeoka 2001. Immunogold labeling of Rubisco in $\mathrm{C}_{4}$ plant leaves for scanning electron microscopy. Plant Prod. Sci. 4 : 41- 49 .

Ueno, O.1992. Immunogold localization of photosynthetic enzymes in leaves of Aristida latifolia, a unique $\mathrm{C}_{4}$ grass with a double chlorenchymatous bundle sheath. Physiol. Plant. 85 : 189-196.

Ueno, O. and S. Agarie 1997. The intercellular distribution of glycine decarboxylase in leaves of cassava in relation to the photosynthetic mode and leaf anatomy. Jpn. J. Crop Sci. 66 : 268-278.

Ueno, O., S.W. Bang, Y. Wada, A. Kondo, K. Ishihara, Y. Kaneko and Y. Matsuzawa 2003. Structural and biochemical dissection of photorespiration in hybrids differing in genome constitution between Diplotaxis tenuifolia $\left(\mathrm{C}_{3}-\mathrm{C}_{4}\right)$ and radish $\left(\mathrm{C}_{3}\right)$. Plant Physiol. 132 : 15501559.

安田健次郎 1986. 免疫化学的方法. 日本電子顕微鏡学会関東支部 (編), 電子顕微鏡生物試料作製法. 丸善, 東京. 219-235.

Yoshimura, Y., F. Kubota and O. Ueno 2004. Structural and biochemical bases of photorespiration in $\mathrm{C}_{4}$ plants: quantification of organelles and glycine decarboxylase. Planta $220: 307-317$. 